\title{
Priority of Key Success Factors (KSFS) on Enterprise Resource Planning (ERP) System Implementation Life Cycle
}

\author{
Zainal Arifin Hasibuan ${ }^{1}$ and Gede Rasben Dantes ${ }^{2}$ \\ ${ }^{1}$ Faculty of Computer Science, University of Indonesia, Depok, Jawa Barat, Indonesia \\ ${ }^{2}$ Department of Information Management, Ganesha University, Singaraja, Bali, Indonesia
}

\begin{abstract}
This study presents the priority of key success factors (KSFs) on Enterprise Resource Planning (ERP) system implementation life cycle. There are twenty KSFs considered in this study. They were chosen from literature review. The KSFs are classified into five stages of ERP implementation life cycle; namely: project preparation, technology selection, project formulation, implementation/development and deployment. To address the study objectives, a survey questionnaire was considered the most appropriate research method. It was sent to 74 companies that have been implementing ERP system for at least one year. The respondents are staff at management level, IT staff and users involved in the development and use of the ERP system. The survey received 248 responses from 740 quesitionnaires that were sent to the companies. To find the priority of KSFs on ERP implementation life cycle, a quantitative analysis is applied to identify the weighting of KSFs toward ERP implementation success. The success of ERP implementation can be measured through five indicators; namely: system quality, information quality, service quality, tactical impact and strategical impact. Based on the weighting of KSFs on each stage of ERP implementation life cycle, it is found that the communication is most critical KSF on project preparation stage $(\rho=0.664)$. While the strong ERP product (package selection) is most critical KSF on technology selection stage ( $\rho=0.554)$. The change management is most critical KSF on project formulation stage $(\rho=0.406)$, and on implementation/development stage, user training is the most critical $\operatorname{KSF}(\rho=0.422)$. This study is expected to improve knowledge in ERP implementation, especially the role of KSF on each stage of ERP implementation life cycle.
\end{abstract}

Keywords: Priority of KSFs, ERP Implementation Success, ERP Implementation Life Cycle, Key Success Factors (KSFs)

\section{Introduction}

Enterprise Resource Planning (ERP) system is an integrated information system that is used to support business processes and resource management within an organization. These systems integrate between one business unit with other business units. With the implementation of this system in an organization to support the company's operations, it is expected to provide optimum benefit for the company.
This is especially needed by the various industrial sectors in this era of globalization. So, the company can compete with competitors or even create a competitive advantage. In addition, ERP selection is also done with various strategic reasons both tangible and intangible.

ERP software has grown rapidly the last 10 years. According to AMR Research, ERP system sales increased dramatically in 2004 reached 23.6 billion dollars. Market

Copyright (C) 2012 Zainal Arifin Hasibuan and Gede Rasben Dantes. This is an open access article distributed under the Creative Commons Attribution License unported 3.0, which permits unrestricted use, distribution, and reproduction in any medium, provided that original work is properly cited. Contact Author: Zainal Arifin Hasibuan E-mail: zhasibua@cs.ui.ac.id 
growth rate remained stable in 2005 , and the end of 2009 the ERP software sales reached 24.5 billion dollars (Hestermann, Anderson \& Pang, 2009). One of the largest ERP companies is SAP AG (a German Company). The company controls about $40 \%$ of the market and it is the third largest software company in the world. Based on data from SAP AG, about $80 \%$ of SAP's sales occur in Europe and the United States, while the remaining $20 \%$ spread in Asia.

The main reason of the investment made by companies is due to the ERP system integration business and it promises to improve the company's competitive position in the market (Luo and Strong, 2004). Some benefits have also been frequently cited in several studies related to the ERP system, such as: data and application integration as a substitute for legacy systems, lower cost and faster deployment compared with in-house development, adopting ERP best practices into business company processes (Markus, 2004). However, some other cases show that investments of Information Technology (IT) with substantial funds may not necessarily bring optimal benefits. This is shown by Dantes \& Hasibuan (2010) who illustrate that nearly $60 \%$ of ERP implementation in Indonesia in both public and private companies have failed. Even big companies in the world such as: FoxMeyer Drug and Dell Computer have spent quite a lot of funds for implementation of ERP but the benefits obtained are not optimal (Kalakota and Robinson, 2001). It was reported that FoxMeyer like all large companies engaged in pharmaceutical declare themselves bankrupt because of failure in implementing the system. In line with the above data, a survey conducted by
Robbins-Giowa in American companies in 2001 found that about $51 \%$ of companies in America have failed in the implementation of ERP (IT Cortex, 2003), In China, it is estimated that the ERP implementation success rate is only $10 \%$ (Zhang et al., 2003).

Success and failure of ERP system implementation is influenced by several aspects of both internal and external organizations. Various factors are influencing the success of ERP implementation. Many researchers found critical success factors on ERP implementation, but they were not put in practice. Therefore, in this study we examine the KSF and propose a priority of KSFs on ERP implementation life cycle, both technical and non technical issues that influence the ERP implementation success.

\section{Theoretical Background}

The following sub sections discuss ERP implementation life cycle, KSFs on ERP implementation process, and measurement of ERP implementation success model.

\section{Implementation Life Cycle}

ERP implementation is changing from legacy systems into ERP system. It is more on process change instead of technology change itself. This section will describe the stages on ERP implementation from previous research, in which each model has different stages. In general, ERP implementation process has three main stages: pre-implementation, implementation and post-implementation (Capaldo and Rippa, 2009). However, some researchers considered each stage to be sub-stages according to their perspectives. 
Table 1: Comparison of ERP Implementation Life Cycle

\begin{tabular}{|c|c|c|c|}
\hline Literature & Pre-Implementation & Implementation & Post-Implementation \\
\hline $\begin{array}{l}\text { Esteves \& Pastor } \\
\text { (1999) }\end{array}$ & $\begin{array}{l}\text { (1) Adoption Stage } \\
\text { (2) Acquisition Stage }\end{array}$ & $\begin{array}{l}\text { (3) Implementation } \\
\text { Stage }\end{array}$ & $\begin{array}{l}\text { (4) Use \& Maintenance Stage } \\
\text { (5) Evolution Stage } \\
\text { (6) Retirement Stage }\end{array}$ \\
\hline $\begin{array}{l}\text { Markus \& Tanis } \\
(2000)\end{array}$ & (1) Chartering Stage & (2) Project Stage & $\begin{array}{ll}\text { (3) } & \text { Shakedown Stage } \\
\text { (4) } & \text { Onward \& Upward Stage }\end{array}$ \\
\hline $\begin{array}{l}\text { Ross \& Vitale } \\
(2000)\end{array}$ & (1) Design Stage & $\begin{array}{l}\text { (2) Implementation } \\
\text { Stage }\end{array}$ & $\begin{array}{l}\text { (3) Stabilization Stage } \\
\text { (4) Continuous Improvement } \\
\text { Stage } \\
\text { (5) Transformation Stage }\end{array}$ \\
\hline $\begin{array}{l}\text { Shanks, Parr, Hu, } \\
\text { Corbitt, } \\
\text { Thanasankit \& } \\
\text { Seddon }(2000)\end{array}$ & (1) Planning Stage & $\begin{array}{l}\text { (2) Implementation } \\
\text { Stage }\end{array}$ & $\begin{array}{l}\text { (3) Stabilization Stage } \\
\text { (4) } \text { Improvement Stage }\end{array}$ \\
\hline $\begin{array}{l}\text { Parr \& Shanks } \\
(2000)\end{array}$ & (1) Planning Stage & (2) Project Stage & (3) Enhancement Stage \\
\hline $\begin{array}{l}\text { Somer \& Nelson } \\
(2004)\end{array}$ & $\begin{array}{l}\text { (1) Initiation Stage } \\
\text { (2) Adoption Stage }\end{array}$ & (3) Adaptation Stage & $\begin{array}{l}\text { (4) Acceptance Stage } \\
\text { (5) Routinization Stage } \\
\text { (6) Infusion Stage } \\
\end{array}$ \\
\hline $\begin{array}{l}\text { Peslak, } \\
\text { Subramanian \& } \\
\text { Clayton (2007) }\end{array}$ & (1) Planning Stage & $\begin{array}{l}\text { (2) Transition Stage } \\
\text { (3) Performance } \\
\text { Stage }\end{array}$ & (4) Enhancement Stage \\
\hline
\end{tabular}

Based on previous research, ERP implementation life cycle is divided into 5 stages: project preparation, technology selection, project formulation, implementation/development and deployment (Dantes \& Hasibuan, 2011a). The description of each stage is provided below:

(1) Project preparation - the preparation stage for the project, such as: defining goal and objective, determining project budget and time, identifying organization maturity level, business process reengineering (if needed), evaluation of Information Technology (IT) investment and analysis of existing information system/information technology (IS/IT), etc.

(2) Technology selection - the selection of technology including: ERP software/application, database and hardware used to support ERP system, determine project team \& steering committee, ERP consultant selection and choosing of ERP implementation strategy \& methodology.

(3) Project formulation - covers the business blueprint that will be used in implementation/development, such as: functional requirement building, development implementation plan, etc.

(4) Implementation/Development - system configuration/customization and makes the system running in production environment

(5)Deployment - stabilizing, eliminating "bugs", maintaining systems, supporting user, getting results, system upgrading and getting to normal operations.

\section{Key Success Factors (KSFs) in ERP Implementation Process}

The KSFs constitute an important part of ERP implementation. In this study, the priority of KSFs is found in each stage of ERP implementation life cycle. Various factors influence an ERP implementation success both technical and non-technical. However, several ERP implementation life cycles emphasize technical factors more than non-technical ones. In this study, KSFs are classified into three attributes including either technical or non-technical factors, namely: people, process \& organization and technology attributes. The factors will be involved in each stage of 
ERP implementation life cycle. The following table is a summary of KSFs that influence ERP implementation success based on several researches.

This study determines the coefficient correlation (weighting) between KSFs and ERP implementation success. Thus, how critical each KSF toward ERP implementation success is acquainted with.
The quantitative analysis using product moment will be used to determine the weighting of each KSF on ERP implementation success. With this weight, the priorities of KSF on ERP implementation success will be known. This is important because the company is not able to fulfill all the KSFs in ERP implementation process.

Table 2: Key Success Factors (KSFs) Classification in ERP Implementation Based on Literatures

\begin{tabular}{|c|c|c|}
\hline Aspects & $\begin{array}{l}\text { Key Success Factors } \\
\text { (KSFs) }\end{array}$ & Literary Support \\
\hline \multirow{4}{*}{ People } & $\begin{array}{l}\text { Top Management } \\
\text { Support }\end{array}$ & $\begin{array}{l}\text { Brown \& Vessey (1999; 2003); Holland \& Light (1999); Esteves \& } \\
\text { Pastor (2000); Parr \& Shanks (2000); Roseman et al. (2001); Allen } \\
\text { et al. (2002); Wenrich et al. (2009); Soja (2006); Yahaya et al. } \\
\text { (2006); Somer \& Nelson (2004); Umble et al. (2003); }\end{array}$ \\
\hline & Team Work & $\begin{array}{l}\text { Wu \& Wong (2007); Soja (2006); Zhang et al. (2006); Somer \& } \\
\text { Nelson (2004); Umble et al. (2003); Mashari (2003); Kumar et al. } \\
\text { (2003); Brown \& Vessey (1999); Holland \& Light (1999) }\end{array}$ \\
\hline & User Involvement & $\begin{array}{l}\text { Esteves \& Pastor (2000); Roseman et al. (2001); Mashari (2003); } \\
\text { Hong \& Kim (2002) }\end{array}$ \\
\hline & Use of Consultant & $\begin{array}{l}\text { Yahaya et al. (2006); Zang et al. (2006); Wu \& Wang (2007); Somer } \\
\text { \& Nelson (2004); Brown \& Vessay (1999); Holland \& Light (1999) }\end{array}$ \\
\hline \multirow{13}{*}{$\begin{array}{l}\text { Process and } \\
\text { Organization }\end{array}$} & Clear Goal and Objective & $\begin{array}{l}\text { Wenrich et al. (2009); Sun et al. (2005); Umble et al. (2003); Kumar } \\
\text { et al. (2003); Holland \& Light (1999) }\end{array}$ \\
\hline & Project Budget & Soja (2006); Yahaya et al. (2006); Sun et al. (2005); \\
\hline & Project Time & $\begin{array}{l}\text { Soja (2006); Yahaya et al. (2006); Tsai et al. (2005); Sun et al. } \\
\text { (2005); Umble et al. (2003); Kumar et al. (2003); Parr and Shanks } \\
\text { (2000); Kale (2000); Holland and Light (1999); Summer (1999) }\end{array}$ \\
\hline & $\begin{array}{l}\text { Organization Maturity } \\
\text { Level }\end{array}$ & Dantes and Hasibuan (2010) \\
\hline & Culture Readiness & $\begin{array}{l}\text { Yahaya et al. (2006); Zhang et al. (2006); Motwani et al. (2005); } \\
\text { Gargeya and Brady (2005); Hong and Kim (2002); }\end{array}$ \\
\hline & $\begin{array}{l}\text { ERP Implementation } \\
\text { Strategy }\end{array}$ & Wenrich et al. (2009); Allen et al. (2002); Holland \& Light (1999) \\
\hline & $\begin{array}{l}\text { ERP Implementation } \\
\text { Methodology }\end{array}$ & Niv Ahituv (2002) \\
\hline & Project Management & Tsai et al. (2005); Somer and Nelson (2004); Bhatti (2005) \\
\hline & Change Management & $\begin{array}{l}\text { Wenrich et al. (2009); Tsai et al. (2005); Motwani et al. (2005); } \\
\text { Brown \& Vessay (1999) }\end{array}$ \\
\hline & Risk Management & Bhatti (2005); Motwani et al. (2005) \\
\hline & $\begin{array}{l}\text { Business Process } \\
\text { Reengineering }\end{array}$ & $\begin{array}{l}\text { Somer \& Nelson (2005); Mashari (2003); Kumar et al. (2003); Hong } \\
\text { \& Kim (2002); Holland \& Light (1999) }\end{array}$ \\
\hline & Communication & Bhatti (2005); Allen et al. (2002) \\
\hline & Training & $\begin{array}{l}\text { Wu \& Wong (2007); Tsai et al. (2005); Umble et al. (2005); Somer \& } \\
\text { Nelson (2004); Kumar et al. (2003) }\end{array}$ \\
\hline \multirow{3}{*}{ Technology } & $\begin{array}{l}\text { Technology } \\
\text { Infrastructure } \\
\end{array}$ & Yahaya et al. (2006); Kumar et al. (2003); Holland \& Light (1999) \\
\hline & $\begin{array}{l}\text { Data analysis and } \\
\text { migration }\end{array}$ & $\begin{array}{l}\text { Soja (2006); Somer \& Nelson (2004); Umble et al. (2003); Hong \& } \\
\text { Kim (2002) }\end{array}$ \\
\hline & Strong ERP product & $\begin{array}{l}\text { Wu \& Wong (2007); Soja (2006); Yahaya et al. (2006); Zhang et al. } \\
\text { (2006); Kumar et al. (2003) }\end{array}$ \\
\hline
\end{tabular}




\section{Measurement of ERP Implementation Success Model}

To know the weighting of KSF on ERP implementation success, the researchers attained the coefficient correlation between KSF and ERP implementation success. In this study ERP implementation success can be measured by system quality, information quality, service quality, tactical impact and strategic impact. It is different from the study by Gable et al. (2003) that measures the Enterprise System Success by 5 indicators, namely: system quality, information quality, satisfaction, individual impact and organizational impact. Whereas McLean and DeLone (2002) measure the information system success by system quality, information quality, service quality, use, user satisfaction and net benefits. This is a revision of the previously proposed model, where the information system success is measured by the following indicators: system quality, information quality, use, user satisfaction, individual impact and organizational impact (McLean and DeLone, 1992). Below, there are indicators used in this study to measure an ERP implementation success in an organization.

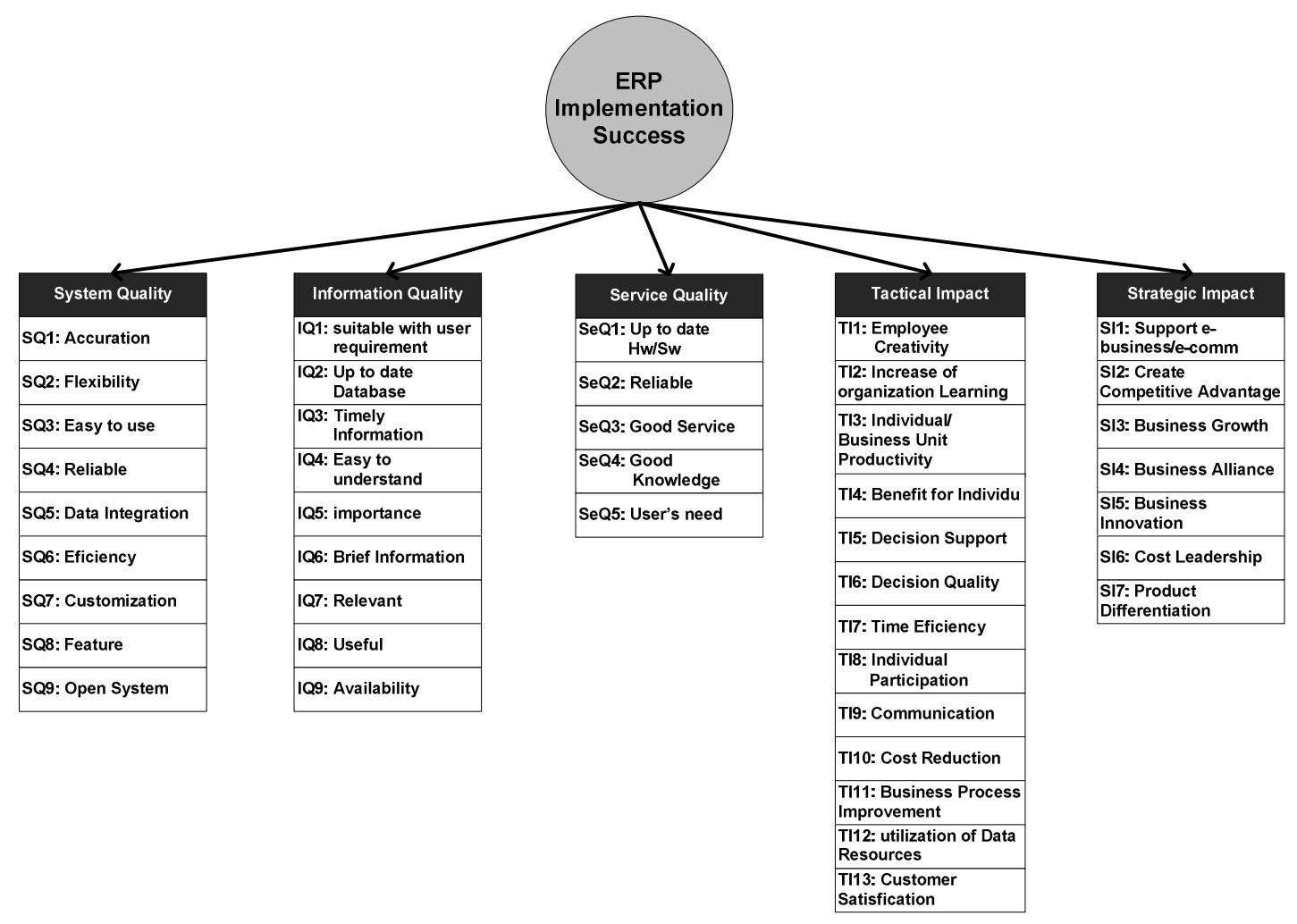

Figure 1. Measurements of ERP Implementation Success (Dantes \& Hasibuan, 2011b)

\section{Research Methodology}

The key objective of this study is to examine a number of issues regarding the weighting of KSFs and to find the priority of KSFs at each stage of ERP implementation life cycle. An ERP implementation success is the score of success in its implementation in an organization. The indicators measured include system quality, information quality, service quality, tactical impact and strategic impact.

List of KSFs are based on literature review that contained: clear goal \& objectives, project budget, project time, ERP implementation strategy, ERP implementation methodology, culture readiness, organization maturity level, top management support, project management, 
change management, risk management, business process reengineering, communication, team work, user involvement, user training, use of consultant, technology infrastructure, data analysis \& conversion and strong ERP product.

To address the study objectives, a survey questionnaire is considered the most appropriate research methodology. It was sent to 74 companies that have been implementing ERP system for at least one year. However, the respondents come from 37 companies representing 10 different industrial sectors. The survey received 248 responses from 740 quesitionnaire sent to the companies. The respondents are staff at management level, IT staff and users involved in the development and use of ERP system. Table 3 shows the characteristics of the sample.

Other than the questionnaire, this present study also conducted interviews and document observation to support the research data. Interviews were conducted with several ERP consultants at the level of technical as well as functional, IT Staffs and with users involved in the ERP implementations. The interviews were conducted in structured and unstructured methods. The questions posed focus on: (1) key success factors on ERP implementation process; (2) ERP implementation success; and (3) ERP implementation process.

\section{Table 3: Sample Characteristics}

\begin{tabular}{|c|c|c|c|c|c|}
\hline Industrial Sectors & Number & Percentage & ERP Products & Number & Percentage \\
\hline $\begin{array}{l}\text { Agroindustri } \\
\text { Automotive } \\
\text { Government } \\
\text { IT Services } \\
\text { Manufacturing } \\
\text { Oil, Gas, Energy \& } \\
\text { Mining } \\
\text { Air Flight Company } \\
\text { Banking } \\
\text { Retail } \\
\text { Telecommunication }\end{array}$ & $\begin{array}{l}1 \\
2 \\
6 \\
8 \\
4 \\
5 \\
2 \\
3 \\
2 \\
4\end{array}$ & $\begin{array}{c}2.70 \% \\
5.41 \% \\
16.22 \& \\
21.62 \% \\
10.81 \% \\
13.51 \% \\
5.41 \% \\
8.11 \% \\
5.41 \% \\
10.81 \%\end{array}$ & $\begin{array}{l}\text { SAP R/3 } \\
\text { Oracle } \\
\text { Enterprise } \\
\text { Axapta } \\
\text { JD Edward } \\
\text { Open source }\end{array}$ & $\begin{array}{c}23 \\
5 \\
3 \\
4 \\
2\end{array}$ & $\begin{array}{c}62.16 \% \\
13.51 \% \\
8.11 \% \\
10.81 \% \\
5.41 \%\end{array}$ \\
\hline $\begin{array}{l}\text { Periods of ERP } \\
\text { Implementation }\end{array}$ & & & $\begin{array}{ll}\text { Number } & \text { of } \\
\text { Employees } & \\
\end{array}$ & & \\
\hline $\begin{array}{l}<=1 \text { year } \\
1-2 \text { years } \\
2-3 \text { years } \\
4-5 \text { years } \\
>5 \text { years }\end{array}$ & $\begin{array}{c}2 \\
4 \\
9 \\
4 \\
18\end{array}$ & $\begin{array}{c}5.56 \% \\
10.00 \% \\
24.44 \% \\
11.11 \% \\
48.89 \%\end{array}$ & $\begin{array}{l}0-100 \\
101-500 \\
501-1000 \\
1001-5000 \\
5001-10,000 \\
>10,000\end{array}$ & $\begin{array}{c}2 \\
7 \\
4 \\
11 \\
9 \\
4 \\
\end{array}$ & $\begin{array}{c}5.68 \% \\
19.32 \% \\
10.23 \% \\
28.41 \% \\
25.00 \% \\
11.36 \% \\
\end{array}$ \\
\hline
\end{tabular}

\section{Discussion \& Result}

This section discusses the weighting of key success factors (KSFs) and priority of KSFs in ERP implementation life cycle.

\section{The Weighting of KSFs on ERP Implementation Success}

To determine the success of ERP implementation in this study, there are 5 components that are measured, namely: system quality (SQ), information quality (IQ), service quality (SEQ), tactical (TAI) and strategical impact (STI). The following figure below shows the weighting of KSF toward SQ, IQ, SEQ, TAI and STI. The researchers also show the weighting of KSF toward ERP implementation success average score of SQ, IQ, SEQ, TAI and STI. 
The Pearson correlation test is used to find the weighting of each KSF toward ERP implementation success. From 248 respondents, there are 14 (5.65\%) respondents as an outlier data (the normality data test is not displayed in this paper). So, from the statistic analysis using Pearson correlation test, only 234 respondents are used as a sample data. The coefficient correlation (weight) between each KSF and component of ERP implementation success is shown in the following table. There is no significant correlation between: (1) Clear goal \& objective $\left(\mathrm{X}_{1}\right)$ and service quality $\left(\mathrm{Z}_{3}\right)$, with $\rho=0.046$; (2) Project time $\left(X_{3}\right)$ and strategic impact $\left(\mathrm{Y}_{2}\right)$, with $\rho=0.069$; (3) Data analysis \& conversion $\left(\mathrm{X}_{19}\right)$ and strategic impact $\left(\mathrm{Y}_{2}\right)$, with $\rho=0.125$. Whereas, other variables have a significant correlation at 0.01 or 0.05 level.

Table 4a: Matrix Correlation All Variables $\left(\mathrm{X}_{1} \ldots \mathrm{X}_{10}\right)(\mathrm{N}=234)$

\begin{tabular}{|c|c|c|c|c|c|c|c|c|c|c|}
\hline & $\mathrm{X}_{1}$ & $\mathrm{X}_{2}$ & $\mathrm{X}_{3}$ & $\mathrm{X}_{4}$ & $\mathrm{X}_{5}$ & $\mathrm{X}_{6}$ & $\mathrm{X}_{7}$ & $\mathrm{X}_{8}$ & $\mathrm{X}_{9}$ & $\mathrm{X}_{10}$ \\
\hline $\mathrm{Z}_{1}$ & $0.206^{*}$ & $0.162^{*}$ & $\begin{array}{c}0.195^{*} \\
*\end{array}$ & $\underset{*}{0.424^{*}}$ & $0.419^{*}$ & $\begin{array}{c}0.385^{*} \\
*\end{array}$ & $\begin{array}{c}0.175^{*} \\
*\end{array}$ & $0.431^{* *}$ & $\begin{array}{c}0.339^{*} \\
*\end{array}$ & $\begin{array}{c}0.256^{*} \\
*\end{array}$ \\
\hline $\mathrm{Z}_{2}$ & $\begin{array}{c}0.238^{*} \\
*\end{array}$ & $\begin{array}{c}0.351^{*} \\
*\end{array}$ & $\begin{array}{c}0.305^{*} \\
*\end{array}$ & $0.44^{* *}$ & $\begin{array}{c}0.538^{*} \\
*\end{array}$ & $\begin{array}{c}0.456^{*} \\
*\end{array}$ & $0.28^{* *}$ & $0.443^{* *}$ & $\begin{array}{c}0.272^{*} \\
*\end{array}$ & $\begin{array}{c}0.271^{*} \\
*\end{array}$ \\
\hline $\mathrm{Z}_{3}$ & 0.046 & $0.31^{* *}$ & $\underset{*}{0.234^{*}}$ & $\underset{*}{0.235^{*}}$ & $\underset{*}{0.332^{*}}$ & $\begin{array}{c}0.459^{*} \\
*\end{array}$ & $\underset{*}{0.286^{*}}$ & $0.306^{* *}$ & $\underset{*}{0.176^{*}}$ & $\underset{*}{0.318^{*}}$ \\
\hline$Y_{1}$ & $\begin{array}{c}0.334^{*} \\
*\end{array}$ & $\begin{array}{c}0.242^{*} \\
*\end{array}$ & $0.16^{*}$ & $\underset{*}{0.417^{*}}$ & $\begin{array}{c}0.451^{*} \\
*\end{array}$ & $\begin{array}{c}0.378^{*} \\
*\end{array}$ & $\underset{*}{0.184^{*}}$ & $0.511^{* *}$ & $\underset{*}{0.511^{*}}$ & $0.35^{* *}$ \\
\hline$Y_{2}$ & $\underset{*}{0.282^{*}}$ & $\begin{array}{c}0.265^{*} \\
*\end{array}$ & 0.069 & $\underset{*}{0.364^{*}}$ & $0.35^{* *}$ & $\begin{array}{c}0.309^{*} \\
*\end{array}$ & $\underset{*}{0.169^{*}}$ & $0.539^{* *}$ & $\begin{array}{c}0.368^{*} \\
*\end{array}$ & $\begin{array}{c}0.418^{*} \\
*\end{array}$ \\
\hline $\mathrm{Y}$ & $0.307^{*}$ & $\begin{array}{c}0.315^{*} \\
*\end{array}$ & $0.219^{*}$ & $0.486^{*}$ & $0.522^{*}$ & $\begin{array}{c}0.473^{*} \\
*\end{array}$ & $0.252^{*}$ & $0.58^{* *}$ & $\begin{array}{c}0.447^{*} \\
*\end{array}$ & $0.406^{*}$ \\
\hline
\end{tabular}

${ }^{* *}$ Correlation is significant at the 0.01 level (2-tailed), ${ }^{*}$ Correlation is significant at the 0.05 level (2-tailed)

Table 4b: Matrix Correlation All Variables $\left(\mathrm{X}_{11} \ldots \mathrm{X}_{20}\right)(\mathrm{N}=234)$

\begin{tabular}{|c|c|c|c|c|c|c|c|c|c|c|}
\hline & $\mathrm{X}_{11}$ & $\mathrm{X}_{12}$ & $\mathrm{X}_{13}$ & $\mathrm{X}_{14}$ & $\mathrm{X}_{15}$ & $\mathrm{X}_{16}$ & $\mathrm{X}_{17}$ & $\mathrm{X}_{18}$ & $\mathrm{X}_{19}$ & $\mathrm{X}_{20}$ \\
\hline $\mathrm{Z} 1$ & $0.241^{* *}$ & $0.325^{* *}$ & $0.508^{* *}$ & $0.458^{* *}$ & $0.348^{* *}$ & $0.317^{* *}$ & $0.127^{*}$ & $0.298^{* *}$ & $0.471^{* *}$ & $0.487^{* *}$ \\
\hline $\mathrm{Z} 2$ & $0.168^{* *}$ & $0.316^{* *}$ & $0.496^{* *}$ & $0.552^{* *}$ & $0.435^{* *}$ & $0.423^{* *}$ & $0.204^{* *}$ & $0.354^{* *}$ & $0.362^{* *}$ & $0.669^{* *}$ \\
\hline $\mathrm{Z} 3$ & $0.216^{* *}$ & $0.164^{*}$ & $0.424^{* *}$ & $0.385^{* *}$ & $0.153^{*}$ & $0.353^{* *}$ & $0.392^{* *}$ & $0.315^{* *}$ & $0.254^{* *}$ & $0.476^{* *}$ \\
\hline $\mathrm{Y} 1$ & $0.425^{* *}$ & $0.48^{* *}$ & $0.643^{* *}$ & $0.346^{* *}$ & $0.376^{* *}$ & $0.341^{* *}$ & $0.287^{* *}$ & $0.336^{* *}$ & $0.386^{* *}$ & $0.366^{* *}$ \\
\hline $\mathrm{Y} 2$ & $0.492^{* *}$ & $0.368^{* *}$ & $0.532^{* *}$ & $0.295^{* *}$ & $0.15^{*}$ & $0.304^{* *}$ & $0.46^{* *}$ & $0.267^{* *}$ & 0.125 & $0.329^{* *}$ \\
\hline $\mathrm{Y}$ & $0.414^{* *}$ & $0.442^{* *}$ & $0.664^{* *}$ & $0.493^{* *}$ & $0.373^{* *}$ & $0.422^{* *}$ & $0.357^{* *}$ & $0.384^{* *}$ & $0.398^{* *}$ & $0.554^{* *}$ \\
\hline
\end{tabular}

${ }^{* *}$ Correlation is significant at the 0.01 level (2-tailed), ${ }^{*}$ Correlation is significant at the 0.05 level (2-tailed)

Legend:

- $\mathrm{X}_{1}$ : clear goal \& objective

- $\mathrm{X}_{2}$ : project budget

- $\mathrm{X}_{3}$ : project time

- $\mathrm{X}_{4}$ : ERP implementation strategy

- $\mathrm{X}_{5}$ : ERP implementation methodology

- $\mathrm{X}_{6}$ : culture readiness

- $\mathrm{X}_{7}$ : organization maturity level

- $\mathrm{X}_{8}$ : top management support

- $\mathrm{X}_{9}$ : project management

- $\mathrm{X}_{10}$ : change management

- $\mathrm{X}_{11}$ : risk management

- $\mathrm{X}_{12}$ : BPR
- $\mathrm{X}_{13}$ : communication

- $\mathrm{X}_{14}$ : team work

- $\mathrm{X}_{15}$ : user involvement

- $\mathrm{X}_{16}$ : user training

- $X_{17}$ : use of consultant

- $\mathrm{X}_{18}$ : technology infrastructure

- $\mathrm{X}_{19}$ : data analysis \& conversion

- $\mathrm{X}_{20}$ : strong ERP product

- $\mathrm{Z}_{1}$ : system quality

- $\mathrm{Z}_{2}$ :information quality

- $\mathrm{Z}_{3}$ : service quality

- $Y_{1}$ : tactical impact

- $\mathrm{Y}_{2}$ :strategical impact

- $Y$ : ERP imp. succe 

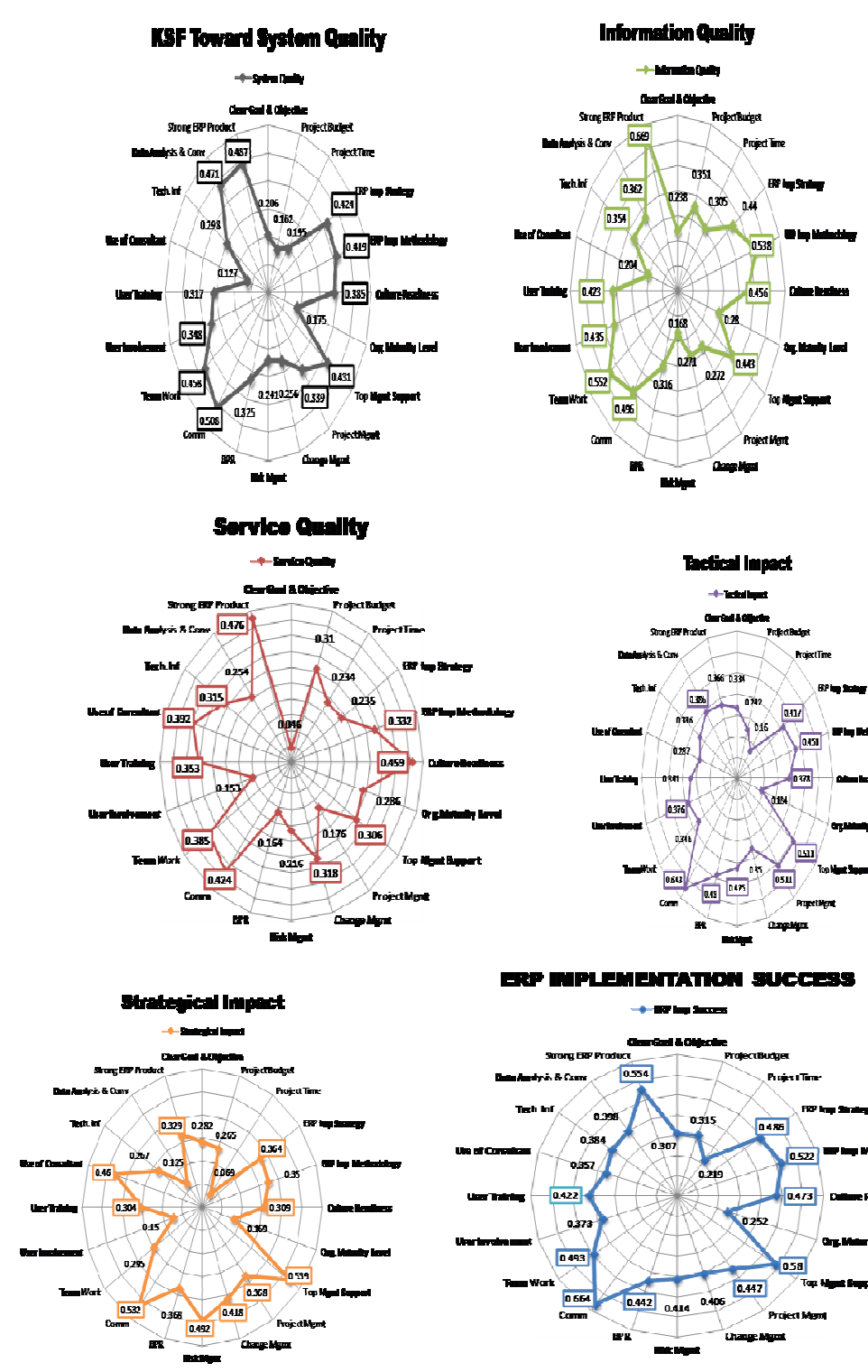

Figure 2. The Weighting of KSFs toward System Quality, Information Quality, Service Quality, Tactical Impact, Strategic Impact and ERP implementation Success (Dantes \& Hasibuan, 2011b)

Focusing on the weighting of KSF on ERP implementation success, there are top ten KSFs which are most influencing on ERP implementation success, namely (figure 2): (1) Communication ( $\rho=0.664)$, (2) Top management support ( $\rho=0.58)$, (3) Strong ERP product $(\rho=0.554)$, (4) ERP implementation methodology $(\rho=0.522)$, (5) Team work ( $\rho=0.493)$, (6) ERP implementation strategy $(\rho=0.486),(7)$ Culture readiness $(\rho=0.473)$, (8) Project management ( $\rho=0.447)$, (9) BPR $(\rho=$ $0.442)$ and (10) User training $(\rho=0.422)$.
Based on this result, the researchers propose the priority of KSFs in ERP implementation life cycle.

\section{The Priority of KSFs in ERP Implementation Life Cycle}

As explained in section 2.1, ERP implementation process is divided into three main stages, namely: preimplementation, implementation and postimplementation. In this study, the preimplementation stage includes project 
preparation and technology selection. Whereas, the implementation stage includes project formulation and implementation/development. And the last stage is post-implementation that includes deployment (operational, support, maintenance and monitoring). Each KSF will be involved into every stage of ERP implementation life cycle in accordance with its function. The red color in figure 3 shows the 10 of most critical factors in ERP implementation success. The detail of each stage is explained below.

\section{Project Preparation Stage}

At project preparation stage, there are nine KSFs involved, namely: team work, identification of organization maturity level, define clear goal \& objective, business process reengineering, project budget \& time, top management support, project management, communication and culture readiness.

Team Work--ERP implementation teams should be composed of people who are chosen for their skills, past accomplishments, reputation and flexibility. These people should be entrusted with critical decision making responsibility (Daneva, 2003; Rothenberger, 2010). The team work has up to $49.30 \%$ role in determining the success of ERP implementation.

Organization maturity level - the organization maturity level is one of the key success factors in ERP implementation success. The higher maturity level of organization is, the higher possibility success will gain, and the lesser the cost to be incurred. The organization maturity level has up to $25.20 \%$ role in determining ERP implementation success.

Clear Goal \& Objective--Clear goals and objectives are essential to guide the organization in achieving the successful implementation of ERP. This is intended to achieve the implementation of ERP in accordance with the time and costs determined and in accordance with company business needs. The clear goal \& objective has up to $30.70 \%$ role in determining the success of ERP implementation.

\section{Business Process Reengineering - business process reengineering is recommended to be done in the process of ERP implementation, in order to gain a competitive advantage for the company. But, it depends on the maturity level of organization and budget \& time available. Business process reengineering has up to $44.20 \%$ role in determining the success of ERP implementation.}

Project Budget \& Time - project budget and time are absolute requirement to be met in the process of ERP implementation. Inadequate budget and time will cause a failure of implementation in this system. The project budget has up to $31.50 \%$ role in determining the success of ERP implementation, while the project time has up to $21.9 \%$.

Top Management Support--Successful implementations require strong leadership, commitment and participation by top management (Holland \& Light, 1999; Lee et al., 2010). They will provide the necessary resources and authorization in order to achieve ERP implementation success (Bhatti, 2005). Management should monitor the project progress and provide clear direction of the project. The top management support has up to $58 \%$ role in determining the success of ERP implementation.

Project Management--Successful ERP implementation requires that the organization engage in excellent project management. This includes a clear definition of objectives, development of both a work plan and a resource plan and careful tracking of project progress (Akkermans \& Helden, 2002). The project plan should establish aggressive - yet achievable - schedules that instill and maintain a sense of urgency (Laughlin, 1999). The project should identify the modules selected for implementation as well as the affected business processes. If management decides to implement a standardized ERP package without major modifications, this will minimize the need 
to customize the basic ERP code. This, in turn, will reduce project complexity and help keep the implementation on schedule. The project management has up to $44.70 \%$ role in determining the success of ERP implementation.

Communication--Communication is one of the most challenging and difficult tasks in an ERP implementation project. It is considered a critical success component in ERP implementation process. It is important to create an understanding, an agreement on implementation and sharing of information among project teams and to communicate the outcomes and goals across the organization within each stage of implementation (Kim et al, 2005). Communication should start early on ERP implementation project. It can include an overview of the system and reasons for applying it as consistently and sustainably (Bhatti, 2005). It has the most important role $(66.40 \%)$ in determining the success of ERP implementation.

Culture Readiness- organizational culture is one of KSFs in ERP implementation. Organization culture that is not ready to accept process change will give negative impact on the ERP implementation. If the culture of the company is not ready for the new technology, resistance on the part of the employees may generate. The culture readiness has up to $47.30 \%$ role in determining the success of ERP implementation.

\section{Technology Selection Stage}

At technology selection stage, there are five KSFs involved, namely: use of consultant, determine ERP implementation strategy, determine ERP implementation methodology, risk management, technology infrastructure and strong ERP product.

Use of Consultant--The selection of appropriate consultant greatly affects the success of ERP implementation. A consultant should be used who has a proper knowledge in the industrial field and ERP system that can help the company to develop and implement a system aligning with the company business's need. Many of ERP consultants have no much experience in ERP implementation process. The use of consultant has up to $35.70 \%$ role in determining the success of ERP implementation.

ERP Implementation Strategy--There are several opinions about the ERP implementation strategy. According to O'Leary (2000), ERP implementation strategy can be divided into: clean sheets, customizing and best of bread. There is also a distinguished classification into: big bang, pilot project (by module) and parallel implementation (Davenport, 2000). The ERP implementation strategy has up to $48.60 \%$ role in determining the success of ERP implementation.

ERP Implementation MethodologyThere are many ERP implementation methodologies available in the market. However, they lay more emphasis on technical, instead of non-technical issues. In this study, it is found that the ERP implementation methodology has a $52.20 \%$ role in determining the success of ERP implementation. 


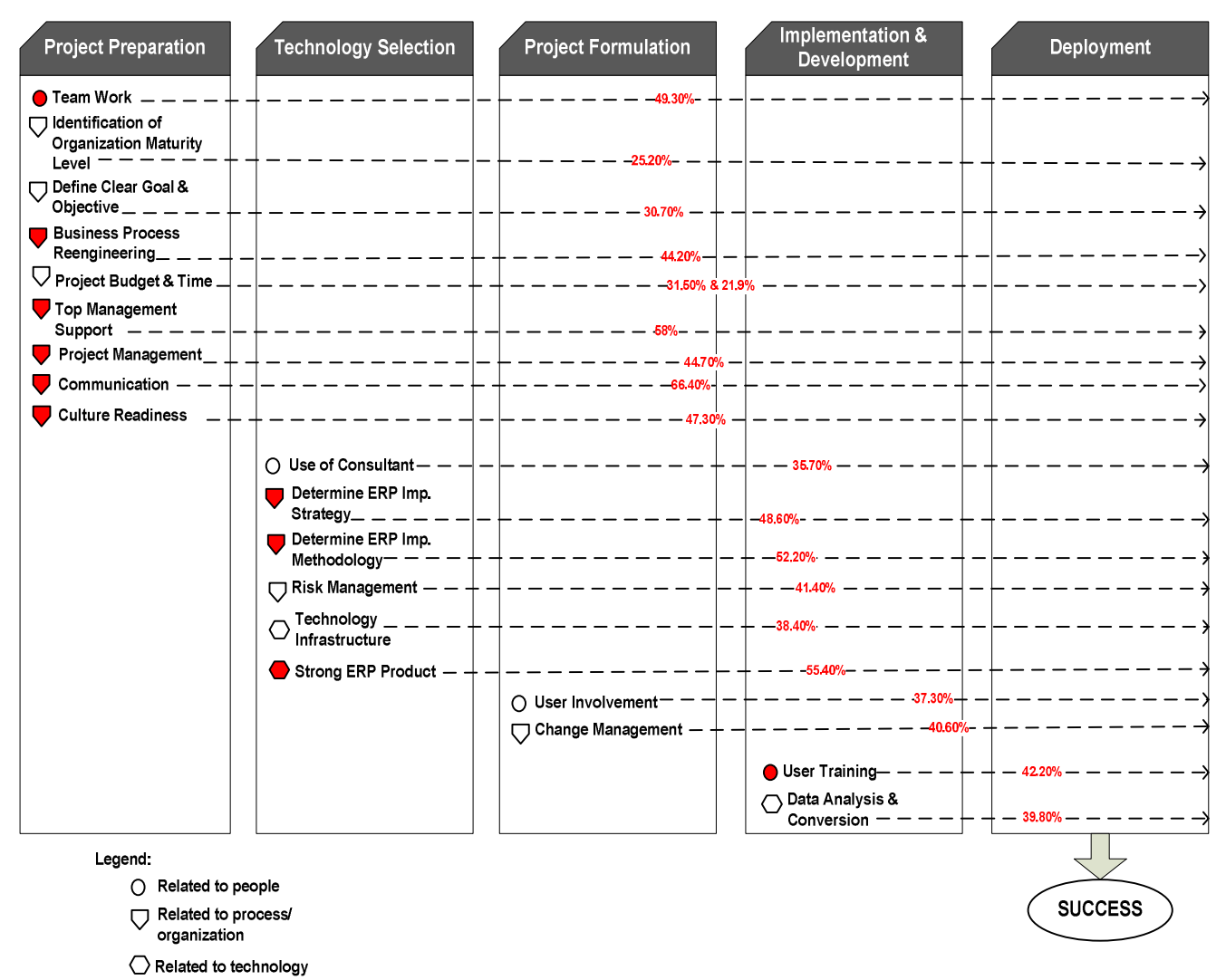

Figure 3. Priority of Key Success Factors (KSFs) on ERP Implementation Life Cycle (Dantes \& Hasibuan, 2011b)

Risk Management-- Donovan (1999) conducted a Risk Management to identify the preparation for facing the occurrence of undesired events. Each project application of IT brings the essential elements of risk because it is likely that progress will deviate from the plan at some point in the project life cycle. ERP implementation project risk is described as uncertainty or vulnerability that could cause the project to deviate from established plans. Good planning and adoption of a systematic risk management are crucial in project completion on time, and on-budget in compliance with all requirements (Iskanius, 2009). The risk management has up to $41.40 \%$ role in determining the success of ERP implementation.

Technology Infrastructure--According to Bhatti (2005), an adequate IT infrastructure, hardware and networking are critical to a successful ERP system implementation. It is clear that ERP implementation involves a complex transition from legacy information systems and business processes into an integrated IT infrastructure and business processes across the organization. The technology infrastructure has up to $38.40 \%$ role in determining the success of ERP implementation.

Strong ERP Product--Strong ERP product is determined by the product selection process. Normally, before the company chooses one of ERP product, it will do the evaluation of the product. However, a lot of companies implement the ERP system because of the technology driven, instead of business driven. Such drive may cause problems. Therefore, the company needs to choose one of them to support its operational process; or the company can use the best of bread strategy (choose the best module from each product). But, this kind of strategy will give the company another integration problem. The strong ERP product has a $55.40 \%$ role in 
determining the success of ERP implementation.

\section{Project Formulation Stage}

At the project formulation stage, there are two KSFs involved, namely: user involvement and change management.

User Involvement--User involvement refers to the psychological state of the individual and is defined as the importance and personal relevance of a system to a user (Bhatti, 2005). It is also defined as a user's participation in the implementation process. The users will be involved in the stage of definition of the company's ERP system needs and also in the implementation of this system. The user involvement has up to $37.30 \%$ role in determining the success of ERP implementation.

Change Management--The existing organizational structure in most companies is not compatible with the structure, tools and types of information provided by ERP systems. ERP system imposes its own logic on a company's strategy, organization and culture. Thus, implementing an ERP system may force the reengineering of key business processes and/or developing new business processes to support the organization's goals (Bernroider \& Koch, 2000). The changes may significantly affect the organizational structures, policies, processes and employees (Dezdar \& Sulaiman, 2009). If people are not properly prepared for the imminent changes, then denial, resistance and chaos will be unavoidable consequences of the changes created by the implementation. However, if proper change management techniques are utilized, the company should be prepared to embrace the opportunities provided by the new ERP system. The organization must be flexible enough to take full advantage of these opportunities (Chang, 2004). The change management has up to $40.60 \%$ role in determining the success of ERP implementation.

\section{Implementation/Development Stage}

In implementation/development stage, there are two KSFs involved, namely: user training and data analysis \& conversion.

User Training-user training is an important critical success component. ERP implementation requires knowledge to enable people to solve problems on the system. If the employees do not understand how a system works, they will invent their own processes using those parts of the system that they are able to manipulate (Laughlin, 1999). The user training has up to $42.20 \%$ role in determining the success of ERP implementation.

\section{Data Analysis \& Conversion}

That is another important thing in ERP implementation process is data analysis and migration. Many problems arise in this process. Thus, the company prefer $0 \mathrm{a}$ different role in ERP implementation success. The role (weight) is determined by using Pearson correlation test. The communication factor has the greatest weight on ERP implementation, with $\rho=0.664$. Whereas, the smallest weight is a project time with $\rho=0.219$. There are five stages in ERP implementation life cycle which are proposed, namely: project preparation, technology selection, project formulation, implementation/development and deployment. At the project preparation stage, the communication is most critical KSF ( $\rho=0.664)$. Whilst, at the technology selection, the strong ERP product (package selection) is most critical KSF $(\rho=0.554)$. At the project formulation, the change management is most critical KSF $(\rho=$ 0.406). Whereas, at implementation/development stage, user training is the most critical KSF $(\rho=0.422)$. This study is expected to improve knowledge in ERP implementation, especially the role of KSF in each stage of ERP implementation life cycle. 


\section{Future Study}

In line with the findings of this study which finds the priority of KSFs in ERP implementation life cycle, further research need to be conducted in order to test the ERP implementation life cycle through a case study.

\section{References}

Akkermans, H. \& van Helden, K. (2002)."Vicious and Virtuous Cycles in ERP Implementation: a Case Study of Interrelations between Critical Success Factors," European Journal of Information Systems, vol.11, Issue. 1, pp. 35-46.

Allen, D., Kern, T. \& Havenhand, M. (2002)."ERP Critical Success Factors: An Exploration of the Contextual Factors in Public Sector Institution," Proceedings of the 35th Hawaii International Conference on System Sciences.

Al-Mashari, M., Al-Mudimigh, A. \& Zairi, M. (2003)."Enterprise Resource Planning: A Taxonomy of critical factors," European Journal of Operational Research.

Bernroider, E. \& Koch, S. (2000)."Differences in Characteristics of the ERP System Selection Process between Small or Medium and Large Organizations," Proceedings of the Sixth Americas Conference on Information Systems, pp. 1022-1028, Long Beach: CA.

Bhatti, T. R. (2005)."Critical Success Factors for the Implementation of Enterprise Resource Planning (ERP): Empirical Validation," The Second International Conference on Innovation in Information Technology (IIT).

Brown, C. \& Vessey, I. (1999).'Managing the Next Wave of Enterprise Systems: Leveraging Lessons from ERP,' MIS Quarterly Executive.

Capaldo, G. \& Rippa, P. (2009)."A PlannedOriented Approach for ERP Implementation Strategy Selection," Journal of Enterprise Information Management, Vol. 22, No. 6, pp. 642-659.
Chung, B. Y., Skibniewski, M. J., Lucas, Jr., H. C. and Kwak, Y. H. (2008)."Analyzing Enterprise Resource Planning system Implementation success Factors in the Engineering - Construction Industry," Journal of Computing in Civil Engineering, $373-382$.

Chang, S.- I. (2004)."ERP life Cycle Implementation, Management and Support: Implications for Practice and Research," Proceedings of the 37 th Hawaii International Conference on System Sciences (HICSS'04) - Track 8.

Dantes, G. R. \& Hasibuan, Z. A. (2010).'The Relationship of Organization Maturity Level and Enterprise Resource Planning (ERP) Adoption (Case study: ERP Implementation in Indonesian Companies),' Proceedings of the 14th International Business Information Management Association Conference, June 23-24, Istanbul, Turkey.

Dantes, G. R. \& Hasibuan, Z. A. (2011a)."Enterprise Resource Planning Implementation Framework Based on Key Success Factors (KSFs)," UK Academy for Information System, 11 - 13 April 2011, Oxford, UK.

Dantes, G. R. \& Hasibuan, Z. A. (2011b).'Step-Wise Approach toward ERP Implementation Success,' Proceedings of 16th IBIMA International Conference, 2930 June 2011, Kuala Lumpur, Malaysia, ISBN: 978-0-9821489-5-2.

Davenport, T. H. (2000).Mission Critical (Realizing the Promise of Enterprise Systems, Boston, Massachusetts, Harvard Business School Press.

Daneva, M. (2003)."Six Degrees of Success or Failure in ERP Requirements Engineering: Experiences with the ASAP Process," International Workshop on COTS and Product Software: Why Requirements are so Important. 11th IEEE International Requirements Engineering conference. Monterey Bay. 
DeLone, W. H. \& McLean, E. R. (1992)."Information System Success: the Quest for the Dependent Variable," Information System Research, 3, 1, pp. 6095.

DeLone, William H. \& McLean, Ephraim R. (2002)."The DeLone and McLean Model of Information System Success," Journal of Management Information Systems, Vol. 19, No. 4, pp. 9-30.

Dezdar, S. \& Sulaiman, A. (2009)."Successful Enterprise Resource Planning Implementation: Taxonomy of Critical Factors," Industrial Management and Data System, Vol. 109, No. 8, pp. 10371052.

Donovan, R. M. (1999)."Strategy and Preparation are Critical Success Factors," http://www.rmdonovan.com/pdf/perfor_9 9_5.pdf.

Ehie, I. C. \& Madsen, M. (2005)."Identifying Critical Issues in Enterprise Resource Planning (ERP) Implementation," Computers in Industry, 56, 545-557.

Esteves, J. \& Pastor, J. (2000)."Toward the Unification of Critical Success Factors for ERP Implementation," Proceedings of the 10th Annual Business Information Technology (BIT) Conference, Manchester, UK.

Esteves, J. M. \& Pastor, J. A. (1999)."An ERP life-Cycle-Based Research Agenda," First International Workshop in Enterprise Management and Resource Planning: Methods, Tools and Architectures (EMRPS), Venice, Italy.

Gable, G. G., Sedera, D. \& Chan, T. (2003)."Enterprise System Success: a Measurement model," Proceedings Twenty-Fourth International Conference on information System, pp. 576-591.

Gargeya, V. B. \& Brady, C. (2005)."Success and Failure Factors of Adopting SAP in ERP System Implementation," Business Process Management Journal.
Kim, Y., Lee, Z. \& Gosain, S. (2005)."Impediments to Successful ERP Implementation Process," Business Process Management Journal, Vol. 11, No.2, pp. 158170.

Laughlin, S. P. (1999)."An ERP Game Plan," Journal of Business Strategy, JanuaryFebruary.

Lee, D. H., Lee, S. M., Olson, D. L. \& Chung, S. H. (2010)."The Effect of Organizational Support on ERP Implementation," Industrial Management and Data System, Vol. 110, No. 2, 2010, pp. 269-283.

Markus, M. L. \& Tanis, C. (1999)."The Enterprise System Experience - from Adoption to Success," Framing the Domains of IT Research: Glimpsing the Future through the Past, chapter 10. Pinnaflex Educational Resources.

Motwani, J., Akbul, A.Y., \& Nidumolu, V. (2005)."Successful Implementation of ERP Systems: a Case Study of an International Automotive Manufacturer," International Journal of Automotive Technology and Management.

Murray, M. \& Coffin, G. (2001)."A Case Study Analysis of Factors for Success in ERP System Implementation," Proceedings of the Americas Conference on Information Systems, Boston, Massachusetts.

Nah, F. F.-H., Lau, J. L.-S. \& Kuang, J. (2001)."Critical Factors for Successfull Implementation of Enterprise Systems," Business Process Management, 7(3), 285296.

O'Leary, D. E. (2000). Enterprise Resource Planning System: systems, life cycle, electronic Commerce, and Risk. Cambridge University Press, Cambridge.

Parr, A. \& Shanks, G. (2000)."A Model of ERP Project Implementation," Journal of Information Technology. 
Roseman, M., Sedera, W. \& Gable, G. (2001)."Critical Success Factors of Process Modeling for Enterprise Systems," Proceedings of the Americas Conference on Information Systems, Boston, Massachusetts.

Rothenberger, M. A., Srite, M. \& JonesGraham, K. (2010)."The Impact of Project Team Attributes on ERP System Implementations," Information Technology \& People, Vol. 23, No.1, pp. 80-109.

Shang, S. \& Seddon, P. B.(2002)."Assessing and Managing the Benefits of Enterprise Systems: the business manager's perspective," Information Systems Journal, 12, pp. 271-299.

Shin, H. \& Lee, J. (1996)."A Process Model of Application Software Package Acquisition and Implementation," Journal of Systems and Software, 32:2, pp. 57-64.

Siau, K. (2001).'ERP Implementation Methodologies - Past, Present, and Future,' Proceedings of the 2001 Information Resources Management Association International Conference (IRMA), Toronto, Canada.

Somers, T. M. \& Nelson, K. G. (2004)."A Taxonomy of Players and Activities across the ERP Project life Cycle," Information and Management.

Summer, M. (2004) Enterprise Resource Planning. Upper Saddle River, New Jersey.

Tsai, W.- H., Chien, S.- W., Hsu, P.- Y. \& Leu, J.- D. (2005)."Identification of Critical Failure Factors in the Implementation of Enterprise Resource Planning (ERP) System in Taiwan's Industries," International Journal of Management and Enterprise Development.

Umble, E. J., Haft, R. R. \& Umble, M. M. (2003)."Enterprise Resource Planning: implementation Procedures and Critical Success Factors," European Journal of Operational Research. 